Plants are key regulators of ecosystem functions such as soil fertility and stability, water availability and pest control. Decisions concerning vegetation management on rangeland should take these multiple considerations into account

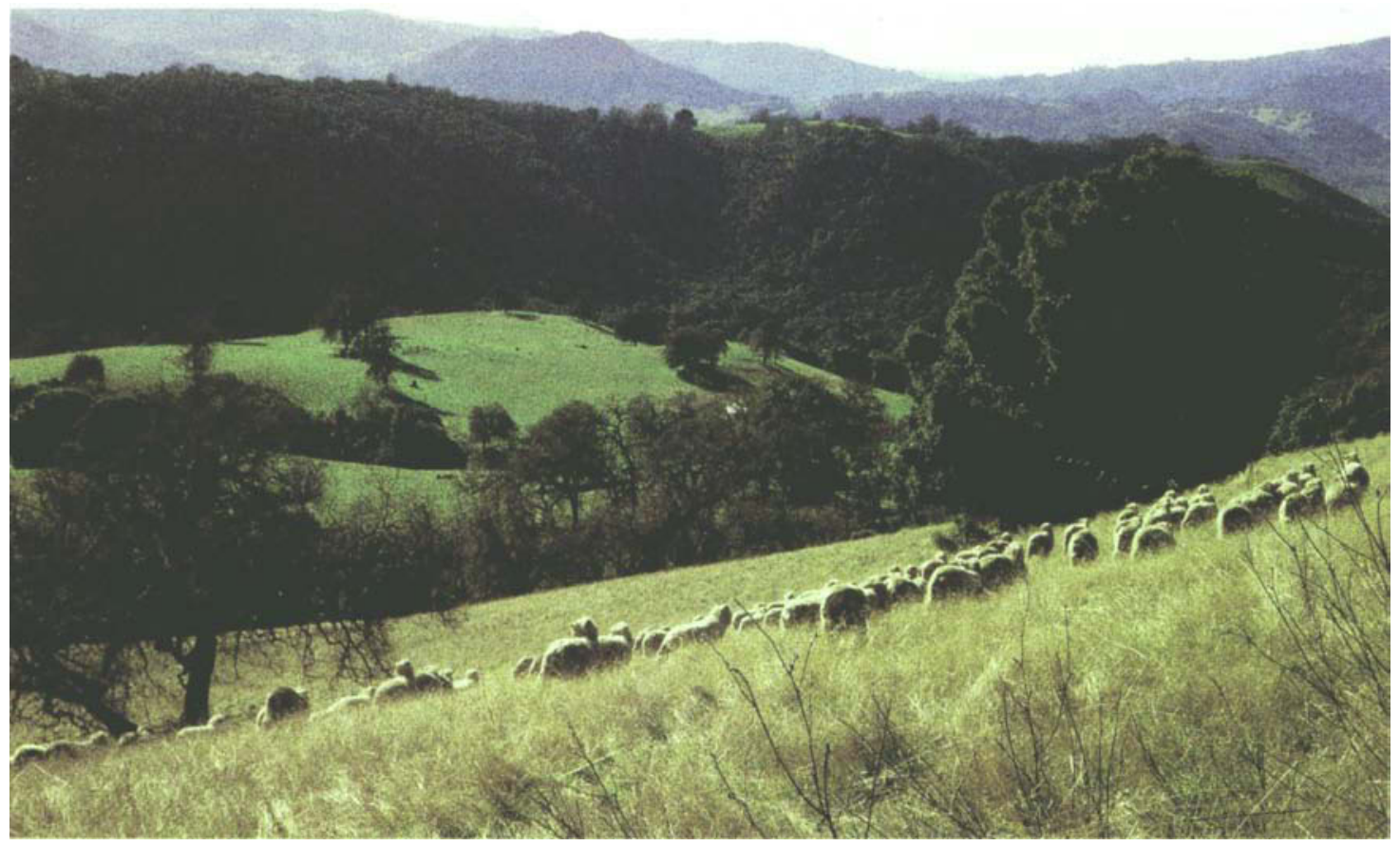

\title{
Plant species provide vital ecosystem functions for sustainable agriculture, rangeland management and restoration
}

\author{
Valerie T. Eviner \ F. Stuart Chapin III
}

\author{
Plants respond to and change \\ their environments, actively \\ altering factors such as soil \\ stability, nutrient and water \\ availability, and the \\ distribution of pests and \\ beneficial organisms. By \\ identifying the functions \\ associated with different \\ species and the effects they \\ have on their ecosystems, \\ managers can use plants as \\ tools in agriculture, range \\ management and restoration, \\ since they will be able to \\ choose plants more effectively \\ and anticipate unintended \\ consequences of vegetation
}

changes. Because cover crops have been used in agricultural settings for years, much is known about their functioning and response to environmental conditions and management practices. Much less is known about plants in natural systems, yet this information can be critical to range management and restoration. We compare what is known about grassland plant functions in California by reviewing the extensive research that has been undertaken at the UC Hopland Research and Extension Center.
$T$ he environmental impacts of con1 ventional agriculture are receiving increased public attention. As pressure intensifies to minimize the use of purchased inputs such as pesticides and fertilizers, it is important to find ways to manage agroecosystems that naturally enhance and sustain fertility, soil stability and water availability, and decrease pests. The plants themselves are the key regulators of these functions. By understanding the roles that different plant species play in ecosystems, managers can use them as tools to enhance crop and forage growth with minimal use of external inputs. However, such uses are often not straightforward. Manipulating vegetation to achieve particular outcomes can result in unintended consequences, as some prior management practices in California demonstrate.

For example, in the 1960s and 1970s, research indicated that large-scale removal of shrubs could increase water 
TABLE 1. Ecosystem functions, tradeoffs, management and environmental conditions associated with cover crops commonly used in California vineyards* $\dagger$

\begin{tabular}{|c|c|c|c|c|c|c|c|c|c|c|c|c|c|c|c|}
\hline \multicolumn{2}{|c|}{ Forbs } & \multicolumn{2}{|c|}{ - } & \multicolumn{4}{|c|}{ Legumes } & \multirow[b]{2}{*}{ 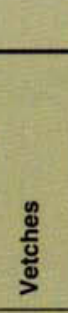 } & \multirow[b]{2}{*}{ 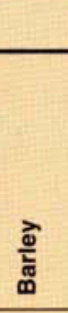 } & \multicolumn{3}{|c|}{ Grasses } & \multirow[b]{2}{*}{ 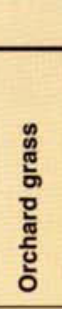 } & \multirow[b]{2}{*}{ 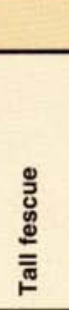 } & \multirow[b]{2}{*}{ 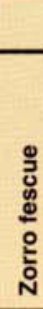 } \\
\hline & 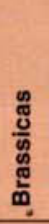 & $\begin{array}{l}\stackrel{\infty}{\bar{\varpi}} \\
\Phi \\
\Phi \\
\overline{\bar{\Phi}} \\
\Phi\end{array}$ & 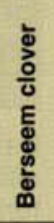 & $\begin{array}{l}\frac{8}{3} \\
\frac{0}{2} \\
\frac{0}{2}\end{array}$ & 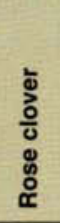 & 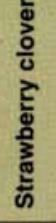 & 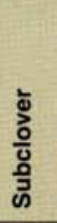 & & & 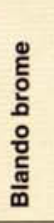 & 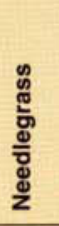 & $\frac{5}{0}$ & & & \\
\hline Functions & & & & & & & & & & & & & & & \\
\hline Adds $\mathrm{N}$ to soil & & $x$ & $x$ & $x$ & $x$ & $x$ & $x$ & $x$ & & & & & & & \\
\hline $\mathrm{N}$ retention & $x$ & & & & & & & & $x$ & & $x$ & $x$ & $x$ & $x$ & $x$ \\
\hline Erosion control & $x$ & & & & $x$ & & $x$ & & $x$ & $x$ & $x$ & $x$ & $x$ & $x$ & $x$ \\
\hline Weed suppression & & & & $x$ & & & $\mathrm{x}$ & & & & & & $x$ & $x$ & \\
\hline $\begin{array}{l}\text { Improves soil structure/ } \\
\text { traction/water penetration }\end{array}$ & & & & & & & & & $\mathrm{x}$ & $\mathrm{x}$ & $\mathrm{x}$ & $x$ & $x$ & $x$ & $\mathrm{x}$ \\
\hline $\begin{array}{l}\text { Removes excess } \\
\text { water }\end{array}$ & & & $x$ & & & & & & & & & $x$ & & & \\
\hline Inhibits nematodes & $x$ & & & & $x$ & & & & & & & & & & \\
\hline $\begin{array}{l}\text { Attracts beneficial } \\
\text { insects }\end{array}$ & $x$ & & & & & & & $\mathrm{x}$ & $\mathrm{x}$ & $\mathrm{x}$ & $\mathrm{x}$ & $x$ & $x$ & $\mathrm{x}$ & $\mathrm{x}$ \\
\hline Opens up heavy soils & $\mathrm{x}$ & $x$ & & & & & & & & & & & & & \\
\hline Negatives & & & & & & & & & & & & & & & \\
\hline Can be weedy & & & & & & $x$ & & & & & & & $x$ & $\mathrm{x}$ & \\
\hline Attracts gophers & & $x$ & $x$ & $x$ & $x$ & $x$ & $x$ & $x$ & & & & & & & \\
\hline $\begin{array}{l}\text { Management } \\
\text { considerations }\end{array}$ & & & & & & & & & & & & & & & \\
\hline Till & & $x$ & $x$ & & & & & $x$ & $x$ & $x$ & & $x$ & & & \\
\hline No-till & & & & $\mathrm{x}$ & $\mathrm{x}$ & $x$ & $x$ & & $x$ & & $\mathrm{x}$ & $x$ & $x$ & $x$ & $x$ \\
\hline Reestablishes well & & & & $x$ & & & & & & $\mathrm{x}$ & & $\mathrm{x}$ & & & $x$ \\
\hline $\begin{array}{l}\text { Does well with } \\
\text { close mowing }\end{array}$ & & & & $x$ & & $x$ & $\mathrm{x}$ & & $x$ & $x$ & $x$ & $x$ & $x$ & $x$ & $x$ \\
\hline Intolerant of mowing & & $x$ & & & & & & & & & & & & & \\
\hline $\begin{array}{l}\text { Does well without } \\
\text { irrigation }\end{array}$ & & & & $x$ & $\mathrm{x}$ & & $x$ & & & $x$ & & & & & $\mathrm{x}$ \\
\hline Site suitability & & & & & & & & & & & & & & & \\
\hline Drought tolerant & & & & $x$ & $x$ & & & & $x$ & & $x$ & & & $x$ & \\
\hline Cold tolerant & & & & $x$ & & & & & & & & & & & \\
\hline Salt tolerant & & & & & & $x$ & & & $\mathrm{x}$ & & & & & & \\
\hline Sandy soils & & & & $x$ & & & & & & & & & & & $\mathrm{x}$ \\
\hline Neutral to basic soils & & & & $x$ & & $x$ & & & & & & & & & \\
\hline Neutral to acid soils & & & & & $x$ & & $x$ & & & & & $x$ & & & \\
\hline
\end{tabular}

runoff, increasing water supply to rivers and streams (Murphy 1976). Although this vegetation manipulation had its intended effect, substantial soil erosion was an unintended outcome (Pitt et al. 1978; Jones et al. 1983). Similarly, from the 1950s through 1970s, oak removal was widely promoted to improve rangeland forage production with less shade and competition from trees. As a result, oaks were removed from more than a million acres in California (IHRMP 1998). The consequences of this practice included de- creased wildlife habitat, substantial soil erosion (IHRMP 1998) and a longterm decrease in soil fertility

(Dahlgren et al. 1997).

These unintended consequences highlight the fact that any plant species can play multiple roles in an ecosystem. By understanding these effects, managers can fully appreciate the tradeoffs associated with a particular vegetation manipulation and maximize its benefits.

Cover crops are an excellent example of how in-depth knowledge of plant species can be applied to land management. Because cover crops have been used extensively in agriculture, there is a wealth of information available, including functions, negative consequences and responses to management and environmental factors (table 1).

For example, although planting legumes can add nitrogen to the agroecosystem, their effectiveness can be maximized by choosing species that provide additional benefits such as erosion control, weed suppression, 


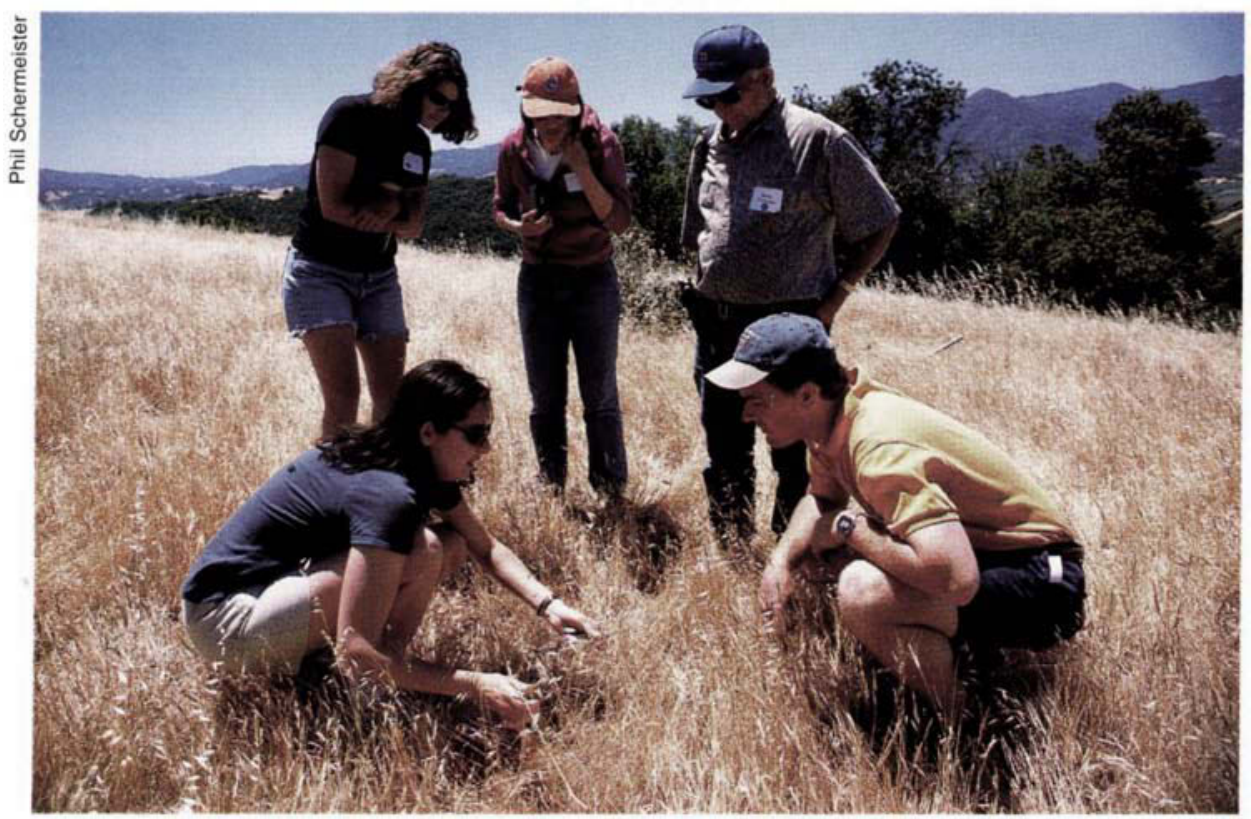

prevention of waterlogging, or the attraction of beneficial insects. This information can also help managers choose species that thrive under environmental conditions and management practices specific to a site, minimizing the need for irrigation and fertilizer. However, there are tradeoffs (table 1). Legumes increase fertility, but they tend to attract gophers, which can damage crops and stimulate erosion. Strawberry clover is the only legume that is appropriate for saline soils, but its tendency to be weedy can outweigh its benefits.

Extensive information exists about plants used in agriculture, but much less is known about California grassland species. Just as farmers can use specific cover crops to provide ecosystem services, the selection of plant species can be invaluable in ranching, range management and restoration. Practices such as the intensity and timing of grazing, fertilization and subclover planting can alter the composition of rangeland vegetation. These shifts can have important effects on forage quality and quantity, erosion control and compaction, water retention and infiltration, and the sustainability of fertility and productivity. By compiling a database of wildland plant characteristics, managers can forge a vital link between the responses of vegetation to management practices and the effects of veg- etation change. This study is a small step toward starting such a database.

Understanding the functions of plants in natural grassland can be very useful for agroecosystems, which could benefit from plants that tolerate or even improve conditions such as pest infestations and lack of nutrients or water that limit productivity. Certain plants can be used to improve soil temperature and microbial communities. Some of the "weeds" that compete with crops in agroecosystems may actually provide crucial services such as pest control or the conservation of nutrients or water.

\section{Effects in California grasslands}

The UC Hopland Research and Extension Center (HREC) has supported decades of research on the effects of grassland plant species on ecosystem functions and the responses of these species to management practices. (For relevant work at other California grassland sites, see Gordon and Rice [1993], Gordon et al. [1989], Hungate et al. [1996], Franck et al. [1997] and Hooper and Vitousek [1997].)

Much of the early research at HREC focused on the response of plant communities to fertilization. Early studies indicated that planting subclover, a nitrogen-fixing plant, in pastures could produce forage yields comparable to pastures fertilized with nitrogen and enhance forage quality in the

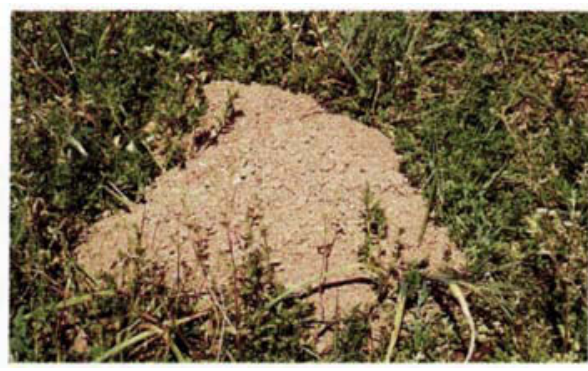

Range species such as forbs, legumes and grasses play an important role in forage quality and quantity. Left, UC Berkeley Ph.D. candidate Valerie Eviner explains the role of plant communities in nutrient cycling during a tour at the UC Hopland Research and Extension Center. Nonplant species such as small mammals also have impacts on plants. For example, in late spring gophers clear legumes from around small feeding mounds. By contrast, in early spring they produce large mounds, above, that bury goatgrass patches.

summer (Jones 1976; Jones and Winans 1967). Fertilizing a subclover planting with nitrogen was found to be counterproductive, since nitrogen fertilization decreases the relative abundance of subclover in the vegetation community (Jones and Evans 1960) (table 2).

More recent work has focused on the ecosystem impacts of different vegetation communities, allowing scientists to link fertilizer-induced shifts in vegetation to ecosystem effects. For example, fertilizing with sulfur, a nutrient often in short supply in California grasslands, increases the abundance of plant species that minimize the loss of sulfur due to leaching (Shock et al. 1983).

Work at HREC has also established the ecosystem consequences of the shift from native perennial grasses to exotic annual grasses (Savelle 1977). The invasion of exotic annual grasses over the past two centuries has displaced native California grassland species such as native perennial grasses. Perennial grasslands dominated by purple needlegrass (Nassella pulchra) have lower decomposition rates than annual grasslands, and higher levels of mulch. Soil organic matter, herbage production, forb (broad-leaved herb) biomass and plant diversity are also lower in perennial grasslands. Perennial grasses have higher root biomass, which is distributed deeper in the soil 
profile. This probably allows the plant to tap deeper sources of water and nutrients and to stabilize soils more effectively. For livestock grazing, annual grasses are preferable because of their higher productivity, nutrient turnover and forb biomass. Perennial grasses are beneficial due to their more effective erosion control and ability to access more water, retaining green forage for longer periods of time. Ideally, rangeland systems could benefit from a mixture of both types of grasses.

Our recent studies at HREC have focused on the effects of eight different California grassland annuals. These species differ strikingly in their effects on ecosystem processes (table 3 ).

Nitrogen availability. Early in the growing season, legumes enhance nitrogen availability. In February, when plants begin their spring growth, high soil nitrogen availability is associated with slender wild oats and soft chess, most likely associated with the timing of nitrogen release from decomposing plant litter. Our data show that managers can use species to manipulate the amount and timing of nitrogen availability. The nitrogen provided by legumes in the fall is critical for maximizing winter forage yields (Jones 1976). However, this early-season pulse of nitrogen availability is accompanied by the potential for substantial nitrogen leaching losses. Grasses are beneficial for maintaining soil nitrogen for plant growth later in the season. Ideally, range management can benefit from pulses of nitrogen provided by both groups of plants, legumes and grasses. The timing of nitrogen release is also important for choosing cover crops, which can be selected based on their ability to provide nitrogen at the time of peak demand by the crop.

Undesirable plant invasions. $\mathrm{Ni}$ trogen availability can also influence invasions by non-native plant species in rangeland. For example, two recent invaders, goatgrass and medusahead, can lower nitrogen availability in the soil (especially during winter), adversely affecting the productivity of desirable grassland species (table 3 ). These invasive species can displace resident species by directly competing

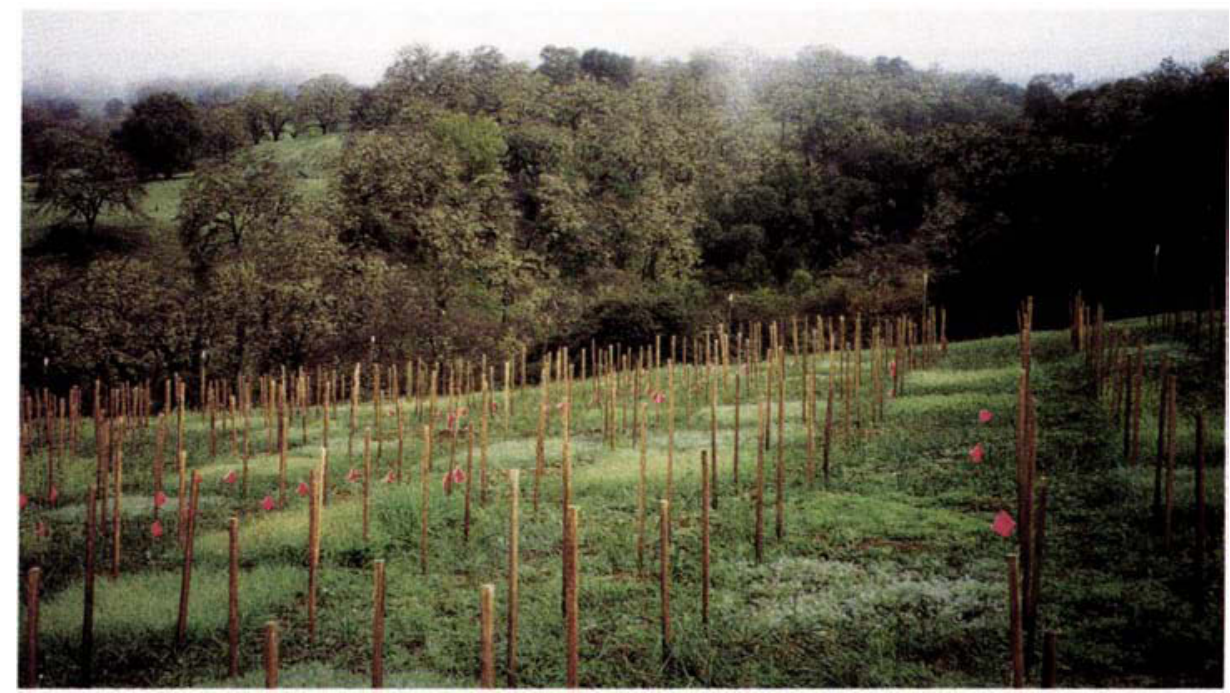

Experimental plots at Hopland were designed to test for the multiple functions that plant species provide to ecosystems.

for resources and by altering the supply of resources available. Even after invasives are eliminated, the changes they make to the ecosystem can persist and prevent the restoration of desirable species, highlighting the need for stringent prevention protocols and swift eradication of invasive species.

Soil structure. In general, grasses provide the most beneficial effects on soil structure. They tend to increase soil aggregation, which can enhance water percolation, soil aeration and soil carbon storage. They also enhance subsurface cohesion, which is critical in decreasing soil erosion. Most grasses cannot provide surface resistance to erosion, but this can be provided by species such as maiden clover, further demonstrating the need for combinations of different plants to achieve maximum benefits (table 3 ).

Small mammals. Plants also alter the activities of other organisms. They can provide food, habitat, prey or predators for other species in the system. For example, mice and voles are associated with plants that produce

\begin{tabular}{|c|c|c|c|c|c|c|c|c|}
\hline & 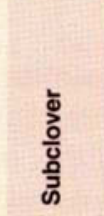 & 产 & 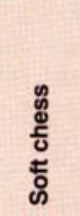 & 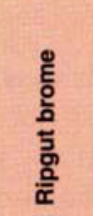 & 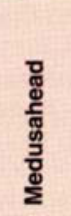 & 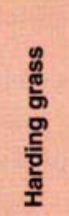 & 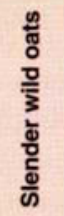 & 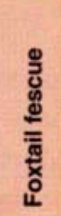 \\
\hline \multicolumn{9}{|l|}{ Plant speciest effects on: } \\
\hline $\begin{array}{l}\text { Volume of water leached } \\
\text { (Shock et al. 1983) }\end{array}$ & High & V. high & Int. & N/A $\ddagger$ & N/A & N/A & N/A & N/A \\
\hline $\begin{array}{l}\text { Fertilizer S loss } \\
\text { (Shock et al. 1983) }\end{array}$ & High & V. high & Int. & N/A & N/A & N/A & $\mathrm{N} / \mathrm{A}$ & N/A \\
\hline \multicolumn{9}{|l|}{ Plant species response to: } \\
\hline $\begin{array}{l}\text { Fertilizer S } \\
\text { (Jones 1963a; Jones 1964) }\end{array}$ & $++1+++$ & 0 & $++1+$ & $+++1+$ & 0 & +++ & $\mathrm{N} / \mathrm{A}$ & N/A \\
\hline $\begin{array}{l}\text { Fertilizer } \mathrm{N} \\
\text { (Evans 1960; Jones 1963b; } \\
\text { Jones and Evans 1960) }\end{array}$ & - & +++ & +++ & ++ & $\mathrm{N} / \mathrm{A}$ & + & +++ & - \\
\hline \multicolumn{9}{|c|}{$\begin{array}{l}\text { - Data on plant species effects on } S \text { fertilizer loss and volume of water leached are presented as comparative rankings: } \\
\text { intermediate (int.), high and very high (v. high). Biomass response to fertilization is indicated by: +++ (large increase), ++ } \\
\text { (increase), }+ \text { (slight increase), } 0 \text { (no response) and -(decrease). }\end{array}$} \\
\hline \multicolumn{9}{|c|}{$\begin{array}{l}\text { † Latin names of species are: subclover (Trifolium subterraneum), filaree (Erodium botrys), soft chess (Bromus } \\
\text { hordeaceous), ripgut brome (Bromus diandrus), medusahead (Taeniatherum caput-medusae), harding grass (Phalaris } \\
\text { tuberosa), slender wild oat (Avena barbata) and foxtail fescue (Festuca megalura). }\end{array}$} \\
\hline \multicolumn{9}{|c|}{$\begin{array}{l}\ddagger \text { N/A indicates that data are not available for this species. When results from separate experiments differ, both sets } \\
\text { of results are presented, with a slash (/) between them. }\end{array}$} \\
\hline
\end{tabular}


TABLE 3: Effects of natural grassland species on ecosystem properties*

\begin{tabular}{|c|c|c|c|c|c|c|c|c|c|}
\hline $\begin{array}{l}\text { Plant speciest } \\
\text { effects on: }\end{array}$ & 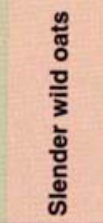 & 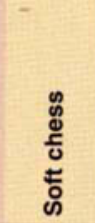 & 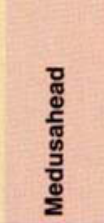 & 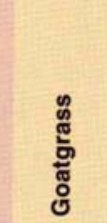 & 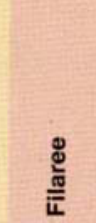 & 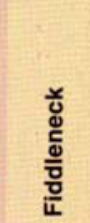 & $\frac{\Xi}{0}$ & 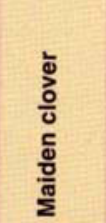 & 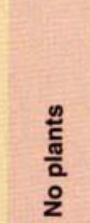 \\
\hline $\mathrm{N}$ availability (fall) & Int. & Int. & Int. & Low & Low & Int. & V. high & V. high & Int. \\
\hline $\mathrm{N}$ availability (winter) . & High & High & Low & Low & Int. & Int. & Int. & Int. & Int. \\
\hline Potential N loss§ (fall) & Int. & Int. & Int. & Int. & Int. & High & V. high & High & High \\
\hline Potential N loss(winter) & Int. & Int. & Int. & Int. : & Int. & Int. & High & High & High \\
\hline$P$ availability (fall) & Low & Low & Low & Low & Low & High & Low & Low & Low \\
\hline Decomposition & Int. & Low & Int. & Low & High & Low & High & High & N/A \\
\hline Mulch quantity & V. high & Int. & High & High & Low & Low & Low & Low & None \\
\hline Tissue $\mathrm{N}$ & Low & Int. & Int. & V. low & Int. & High & V. high & V. high & N/A \\
\hline $\begin{array}{l}\text { Soil moisture } \\
\text { availability (spring) }\end{array}$ & High & Low & Int. & Int. & Int. & Int. & Int. & Low & V. high \\
\hline $\begin{array}{l}\text { Probability of } \\
\text { soil frost }\end{array}$ & V. low & V. low & Int. & Int. & Int. & High & High & High & High \\
\hline Soil aggregation\# & High & $\mathrm{N} / \mathrm{A}$ & V. high & High & N/A & V. low & N/A & Int. & $N / A$ \\
\hline $\begin{array}{l}\text { Soil cohesion } \\
\text { surface }\end{array}$ & Low & Int. & Low & High & V. low & Low & V. low & Int. & V. low \\
\hline $\begin{array}{l}\text { Soil cohesion } \\
\text { subsurface** }\end{array}$ & Int. & High & High & V. high & Low & Low & Int. & Int. & V. low \\
\hline Gopher disturbancett & Int. & Low & Low & V. high & Low & Low & High & High & Low \\
\hline Mice/voles activity & V. high & High & Int. & High & Low & Int. & Low & Int. & Int. \\
\hline \multirow{2}{*}{\multicolumn{10}{|c|}{$\begin{array}{l}\text { † Latin names of species are: slender wild oats (Avena barbata), soft chess (Bromus hordeaceous), medusahead } \\
\text { (Taeniatherum caput-medusae), goatgrass (Aegilops triuncialis), filaree (Erodium botrys), fiddleneck (Amsinckia } \\
\text { douglasiana), lupine (Lupinus bicolor) and maiden clover (Trifolium microcephalum). } \\
\ddagger \text { Nitrogen availability was determined by net } \mathrm{N} \text { mineralization rates. }\end{array}$}} \\
\hline & & & & & & & & & \\
\hline \multicolumn{10}{|c|}{$\begin{array}{l}\text { § Potential } \mathrm{N} \text { loss was determined by net nitrification rates and confirmed by inorganic } \mathrm{N} \text { concentrations. There were no } \\
\text { differences in } \mathrm{N} \text { cycling rates between species in the spring. }\end{array}$} \\
\hline \multicolumn{10}{|c|}{ I Soil moisture availability and gopher disturbance were determined in April. } \\
\hline \multicolumn{10}{|c|}{ \# Source: Rillig et al. in press. } \\
\hline $\begin{array}{l}\text { " Subsurface soil cohes } \\
\text { t† Source: V.T. Eviner. T }\end{array}$ & sion was $m$ & $\begin{array}{l}\text { asured at } \\
\text { significant }\end{array}$ & $\begin{array}{l}\text { a depth of } \\
\text { differences }\end{array}$ & 1 inch. & & & & & \\
\hline
\end{tabular}

high quantities of litter, such as wild oats, goatgrass and soft chess (table 3 ). Manipulation of the residual dry matter in pastures may counterbalance these effects.

Gophers are also associated with certain plant species. In late spring, gopher activity is centered around patches of legumes. Gophers produce small feeding mounds with minimal soil disturbance, and clear legumes from around these mounds. In contrast, in early spring gophers produce large mounds, which essentially bury patches of goatgrass. Gophers appear to selectively build mounds around goatgrass because its substantial root biomass increases soil stability, decreasing the energy gophers need to burrow there (table 3 ).

\section{Vegetation management. Al-} though legumes enhance nitrogen availability, they also increase leaching potential and gopher disturbance, and provide only limited protection against frost and erosion. Understanding these types of tradeoffs can be critical. By growing plants in combination, some of these tradeoffs can be not disturb grass-legume mixtures. Planting a mixed grass-legume plot decreases the potential for nitrogen addition to the soil, but also decreases nutrient leaching (Jones et al. 1974). Such mixtures may be more valuable than legumes alone because the associated decrease in gopher disturbance protects crops from damage and limits nitrogen loss via soil erosion. averted. In recent studies gophers did

\section{Future directions}

One species often does not provide the ideal combination of functions for an agroecosystem. More desirable scenarios are associated with a mixture of vegetation functions:

Annual grasses can enhance productivity, forb biomass and nutrient turnover, while perennial grasses can extend the season of green forage and decrease soil erosion.

Surface and subsurface resistance to soil erosion is associated with different plant species.

Legumes provide nitrogen to the agroecosystem, but can be counterproductive in other ways. Combining legumes with grasses can decrease erosion, reduce soil frost heaving (frost that causes soil movement, which kills plants) and gopher disturbance.

By using a combination of plant species, managers have the ability to attain the most desirable suite of functions, which single species cannot provide alone. However, the effects of species combinations on ecosystem functions often cannot be predicted based on the individual effects of the component species. Species alter one another's growth and traits, as well as soil conditions, so that plant combinations can have unexpected effects on services such as nitrogen fixation, leaching, decomposition and nitrogen cycling.

In natural systems, plants rarely exist as monocultures. The combination of species often provides pest control, higher productivity, longer growing seasons and high nutrient retention. In addition, a diverse plant community is more likely to contain species that flourish despite environmental fluctuations.

Ongoing research at HREC has provided important information on California grassland species, and continues to highlight the need to develop a strategy for growing plant mixtures in which the component species have minimal effects on one another's functions. For example, by minimizing 


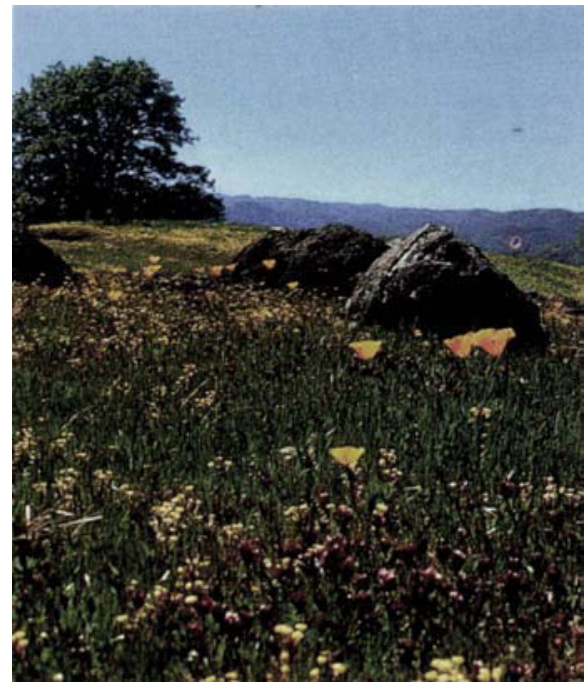

overlap between root systems of mixed species communities, soil water can be used more efficiently and productivity enhanced (Brown 1998). The use of plant species to provide ecosystem functions may be one of the most effective tools in sustainable agriculture. However, it will be important to determine how the functions of individual plant species change in mixed plant communities and how plant functions vary in response to management practices and the environment.

\section{V.T. Eviner is Ph.D. Candidate, Depart-} ment of Integrative Biology, UC Berkeley; and F.S. Chapin III is Professor, Institute of Arctic Biology, University of Alaska. Chuck Vaughn, Bob Keiffer and the HREC staff provided invaluable assistance. Thanks to Lynn Huntsinger and an anonymous reviewer for comments that greatly improved this paper. Funding was provided to the senior author by the UC Sustainable Agriculture Research and Education Program graduate award, NASA Earth System Science Fellowship, National Science Foundation Dissertation Improvement Grant, and National Science Foundation predoctoral fellowship.

\section{References}

Brown CS. 1998. Restoration of California Central Valley grasslands: Applied and theoretical approaches to understanding interactions among prairie species. Ph.D. dissertation, UC Davis library.

Dahlgren R, Singer M, Huang X. 1997. Oak tree and grazing impacts on soil proper-

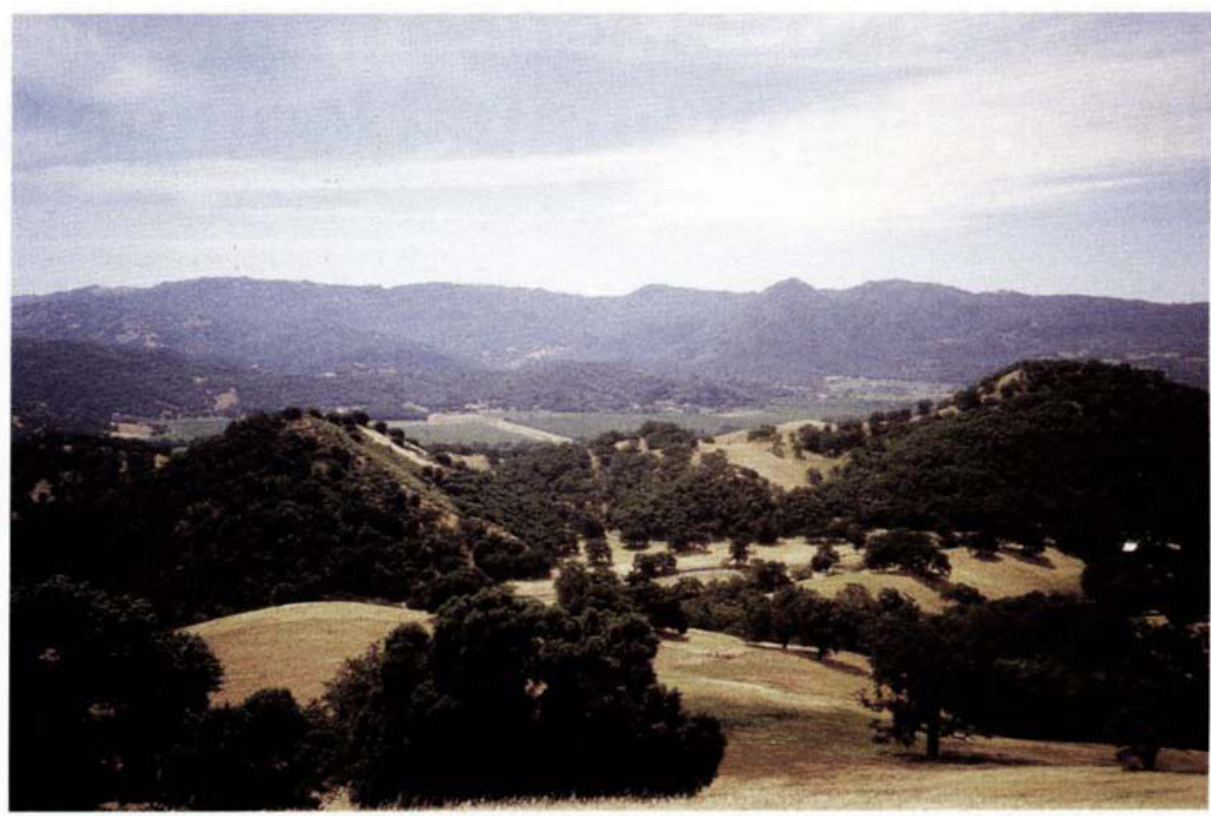

In natural systems, plants rarely exist as monocultures; a diverse plant community is more likely to contain species that flourish despite environmental fluctuations. Understanding the role of plant species in ecosystem functions can be critical for land uses such as rangelands (foreground) and agriculture (background).

ties and nutrients in a California oak woodland. Biogeochem 39(1):45-64.

Evans R. 1960. Differential responses of three species of annual grassland type to plant competition and mineral nutrition. Ecology $41(2): 305-10$.

Franck V, Hungate B, Chapin FS III, Field C. 1997. Decomposition of litter produced under elevated $\mathrm{CO}_{2}$ : Dependence on plant species and nutrient supply. Biogeochem 36(3):223-37

Gordon D, Rice K. 1993. Competitive effects of grassland annuals on soil water and blue oak (Quercus douglasii) seedlings. Ecology $74(1): 68-82$.

Gordon D, Welker J, Menke J, Rice K. 1989. Competition for soil water between annual plants and blue oak (Quercus douglasii) seedlings. Oecologia 79(4):533-41.

Hooper D, Vitousek P. 1997. The effects of plant composition and diversity on ecosystem processes. Science $277(5330): 1302-5$.

Hungate B, Canadell J, Chapin FS III. 1996. Plant species mediate changes in soil microbial $\mathrm{N}$ in response to elevated $\mathrm{CO}_{2}$. Ecology 77(8):2505-15.

[IHRMP] Integrated Hardwood Range Management Program. 1998. Seventh progress report. UC DANR, http:// danr.ucop.edu/ihrmp/7progress.html. Ingels C, Bugg R, McGourty G, Christensen L (eds.). 1998. Cover Cropping in Vineyards: A Grower's Handbook. UC DANR No. $3338.168 p$.

Jones M. 1963a. Effect of sulfur applied and date of harvest on yield, sulfate sulfur concentration, and total sulfur uptake of five annual grassland species. Agron J 55(3):251-4.

Jones M. 1963b. Yield, percent nitrogen and total nitrogen uptake of various California annual grassland species fertilized with in- creasing rates of nitrogen. Agron $\mathrm{J}$ 55(3):254-7.

Jones M. 1964. Effect of applied sulfur on yield and sulfur uptake of various California dryland pasture species. Agron $\mathrm{J}$ 56(2):235-7.

Jones M. 1976. Fertility studies reveal plant and soil needs. Cal Ag 30(7):13-5.

Jones M, Evans RA. 1960. Botanical composition changes in annual grassland as affected by fertilization and grazing. Agron $\mathrm{J}$ 52(8):459-61.

Jones $M$, Koenigs $R$, Vaughn $C$, Murphy H. 1983. Converting chaparral to grassland increases soil fertility. Cal Ag 37(9-10):23-4 Jones M, Street J, Williams W. 1974. Leaching and uptake of nitrogen applied to annual grassland clover-grass mixtures in lysimeters. Agron J 66(2):256-8.

Jones M, Winans SS. 1967. Subterranean clover vs. nitrogen-fertilized annual grasslands: Botanical composition and protein content. J Range Manage 20(1):8-12.

Murphy AH. 1976. Watershed management increases rangeland productivity. Cal $\mathrm{Ag} \mathrm{30(7):16-21.}$

Pitt M, Burgy R, Heady H. 1978. Influences of brush conversion and weather patterns on runoff from a Northern California watershed. J Range Manage 31(1): 23-7.

Rillig MC, Wright SF, Eviner VT. In press. The role of arbuscular mycorrhizal fungi and glomalin in soil aggregation: Comparing effects of five plant species. Plant \& Soil.

Savelle G. 1977. Comparative structure and function in a California annual and native bunchgrass community. Ph.D. dissertation, UC Berkeley library. $276 p$.

Shock C, Jones M, Williams W, Center D. 1983. Effect of sulfur fertilization on three annual range species. I. Laughlin soil experiment. Agron J 75(3): 515-20. 